\title{
Bacteria in Indian Food Packaging Papers and Paperboards with Various Contents of Pulp Fiber
}

\author{
Swati Sood, Chhaya Sharma* \\ Environmental Research Laboratory, Department of Paper Technology, Indian Institute of Technology Roorkee, Saharanpur \\ Campus, Saharanpur, India \\ Email: *chhaya1964@rediffmail.com
}

How to cite this paper: Sood, S. and Sharma, C. (2019) Bacteria in Indian Food Packaging Papers and Paperboards with Various Contents of Pulp Fiber. Food and Nutrition Sciences, 10, 349-357. https://doi.org/10.4236/fns.2019.104027

Received: March 5, 2019

Accepted: April 6, 2019

Published: April 9, 2019

Copyright () 2019 by author(s) and Scientific Research Publishing Inc. This work is licensed under the Creative Commons Attribution International License (CC BY 4.0).

http://creativecommons.org/licenses/by/4.0/

\section{cc) (i) Open Access}

\begin{abstract}
The food packaging industry generally uses papers and paperboards (PPBs) especially for disposable products. According to the Framework Regulation (EC) No. 1935/2004 of the European Union, no transfer of contamination should occur from food packaging material to the food items. The aim of this study was to determine the presence, numbers, source and different kinds of bacteria present in food packaging PPBs with various contents of pulp fiber. The samples were randomly collected from popular confectioners and fast food restaurants in Saharanpur, India. The results indicated the presence of bacteria in all the samples, ranging from $1.3 \times 10^{2}$ to $6.1 \times 10^{3} \mathrm{cfu} / \mathrm{g}$. Most of the samples contained bacteria in more than the permitted concentration of $2.5 \times 10^{2} \mathrm{cfu} / \mathrm{g}$ as set by Food and Drug Administration (FDA). The detected bacteria were from genera Bacillacea, Staphylococcus and Pseudomonas. According to the FDA declaration, pathogenic bacteria such as B. cereus and $S$. aureus have been associated with food borne diseases (FBD). Some contaminants in food packaging PPBs were found to be B. subtilis and P. aeroginosa, which produce enzymes like peroxidases and lipoxygenases that are odor generating enzymes.
\end{abstract}

\section{Keywords}

Bacteria, Odor, Health Safety, Food Packaging Papers and Paperboards (PPBs), Pulp Fiber

\section{Introduction}

Since many years, the food packaging industry has been using disposable paper based materials such as boxes, bags, cups, containers, plates, sacks, and tissue 
papers. The biggest advantage of using such materials in place of other materials is that they do not affect the environment and are biodegradable in nature [1]. Due to changes in operating conditions, laws, strict international competition and increasing demand from the consumers, the role of maintaining proper hygiene and management of microbes in the paper and food packaging industry has increased [2]. There should not be any transfer of components from food packaging material to food in any such way that it could affect the health of human beings, bring a change in the food product in a way that is not acceptable or degrades the taste and odor of food [1]. During paper production, microbial contamination can occur from various sources like water which has been recycled, use of raw materials, various parts of the machine and from the environment of the factory [3]. In the environment of producing and processing paper, a large number of microbes are present but only few of these microbes are harmful. The microbes which produce slime or are filamentous in nature are harmful to the process, while the microbes which produce toxins and odor are harmful to the safety of end products [4]. Odor in the food packaging PPBs is generated due to enzymatic and non-enzymatic oxidation of fatty acids [5]. PPBs contain large amounts of saturated and unsaturated fatty acids [6]. B. subtilis and $P$. aeroginosa, produce enzymes like peroxidases and lipoxygenases respectively [7] [8], which act as catalysts for inserting oxygen in fatty acids which contain methylene interrupted dienes causing oxidation of fatty acids by enzyme action and hence odor generation in the PPBs food packages. Globin proteins (hemoglobin and myoglobin) release ferric ion at high temperatures, and catalyze the production of odorous volatile oxidation products of fatty acids [9]. This is especially undesirable in producing aseptic food packages as it lowers the hygienic quality of the product [10]. Pseudomonas sp. and Bacillus sp. are the pre-dominant bacteria present in agro-wastes [11]. The raw materials used for the purpose of PPBs are biodegradable in nature. However, the disadvantage of this fact is that microbes may grow in such a natural biodegradable raw material and cause contamination in the PPBs [12]. Presently, there are very few published reports on the bacteriological safety of food PPBs. Thus, the knowledge on Indian food PPBs containing bacterial species and their potential to cause food borne diseases and odor generation is also less. The purpose of this research is to gain knowledge on the bacteria present in Indian food PPBs with various contents of pulp fiber, as the first step for creating a basis for assessing the risk to packaged food.

\section{Materials and Methods}

\subsection{Sample Collection}

A total of 10 samples were collected from local nearby markets of Saharanpur in India in January 2019. The samples included paper plate, cake box, fruit tray, tissue paper, coffee cup, pastry box, sweet box, pizza box, French fries box, and paper bag. In additional testing, 3 samples of each group of food packaging PPBs 
were purchased from the local retail outlets.

\subsection{Examination of Pulp Fiber \% in the Samples}

The pulp fiber \% in the samples was determined by IS 5285 (1998): Fiber Analysis of Paper and Board-Methods of Test [CHD 15: Paper and its products] method.

\subsection{Examination of the Total Number of Microorganisms in the Samples}

The international standard method which is based on the disintegration of paper (ISO 8784-1:2005) was used to examine the total number of colony forming units (CFU) of bacteria. $1 \%$ fiber suspension was obtained by disintegrating $1 \mathrm{~g}$ of sample paper in cooled sterile Ringers solution. In the nutrient agar petri plates different dilutions of the fiber suspension were plated. Petri plates were then placed in an incubator at a temperature of $37^{\circ} \mathrm{C} \pm 1^{\circ} \mathrm{C}$ for the duration of $48 \pm 3 \mathrm{~h}$. After the incubation was complete, the total number of CFUs was estimated and the concentrations of bacteria present in $1 \mathrm{~g}$ of paper were calculated. The average values obtained by carrying out the experiments in duplicate are presented in this study [1].

\subsection{Isolation of Pure Colonies by Streak Plate Method}

A sterilized transfer needle was used to obtain a loop of bacteria from the grown colonies. A solidified nutrient agar plate was taken and the loop of bacteria in the sterilized transfer needle was then streaked on it to make a series of non-overlapping, parallel streaks. The plates were incubated at $35^{\circ} \mathrm{C}$, in an inverted position for the time of around $48-72$ hours to obtain bacteria that are pure in nature i.e. bacteria which has been obtained from a single cell [13].

\subsection{Biochemical Tests}

Morphological and Physiological tests (Gram stain, Agar slant cultural characteristics, Starch hydrolysis, Lactose, Dextrose, Sucrose, $\mathrm{H}_{2} \mathrm{~S}$ production, Indole production, MR reaction, VP reaction, Citrate use, Urease activity, Catalase activity, and Oxidase activity) were carried out on the pure bacterial colonies using conventional methods. The characteristics of bacterial species were identified based on the Bergey's Manual (Claus and Berkeley 1986).

\section{Results and Discussions}

The bacterial contamination of Indian food packaging PPBs with various content of pulp fiber was investigated. Our findings showed that from the 10 tested food packaging PPBs, bacteria was present in all the samples. Table 1 summarizes the results obtained from the bacterial analysis of the total numbers of bacteria in the food packaging PPBs. Total number of bacteria ranged from $1.3 \times$ $10^{2}$ to $6.1 \times 10^{3} \mathrm{cfu} / \mathrm{g}$. Our results are comparable with Mohammadzadeh findings which showed the range of $0.2 \times 10^{3}$ to $>1 \times 10^{5} \mathrm{cfu} / \mathrm{g}$ bacterial contamination in food packaging paperboards [14]. According to FDA declaration, the 
Table 1. Total number of bacteria identified in the examined samples.

\begin{tabular}{cc}
\hline Sample & Number of Bacteria $(\mathrm{cfu} / \mathrm{g})$ \\
\hline (Permitted conc.) & $\left(2.5 \times 10^{2}\right)$ \\
Paper plate & $6.7 \times 10^{2}$ \\
Cake box & $8.7 \times 10^{2}$ \\
Fruit tray & $6.1 \times 10^{3}$ \\
Tissue paper & $1.3 \times 10^{2}$ \\
Coffee cup & $3.2 \times 10^{2}$ \\
Pastry box & $6.9 \times 10^{2}$ \\
Sweet box & $7.6 \times 10^{2}$ \\
Pizza box & $9.8 \times 10^{2}$ \\
French fries box & $7.2 \times 10^{2}$ \\
Paper bag & $4.8 \times 10^{2}$ \\
\hline
\end{tabular}

limit value recommendations for packaging materials is $2.5 \times 10^{2}$ bacterial cfu/g [15] [16]. In our study, samples of tissue paper contained less bacteria than the permitted concentration, while all the other samples contained bacteria in more than the permitted concentration. The minimum bacteria number was found in tissue paper $\left(1.3 \times 10^{2}\right)$ and the maximum bacteria number was found in fruit tray $\left(6.1 \times 10^{3}\right)$. A study by Guzińska et al. also shows that the number of microbes that were estimated in paperboard are much higher than in paper as shown by our results too [17].

Based on the colony morphology, gram staining and biochemical tests, four different bacterial strains were identified which included B. cereus, B. subtilis, $S$. aureus and $P$. aeroginosa (Figure 1).

Out of 10 samples which were tested, three samples were contaminated with B. subtilis, four samples with $B$. cereus, two samples with $S$. aureus and one sample with $P$. aeroginisa (Table 2).

The various \% of pulp fibers in the samples are shown in Figure 2. In comparison to chemical pulping, the mechanical pulping causes the disintegration of wood into fibers to yield pulp having different characteristics. The pulp still contains the lignin due to which although the yield is higher, but the strength is low. A paper mill is generally equipped with the production of mechanical pulp [18]. In chemical pulping kraft process is the most commonly used process for a variety of end uses [19]. The maximum \% of agro-residues, softwood mechanical pulp, softwood chemical pulp and hardwood chemical pulp was present in cake box, pizza box, coffee cup and tissue paper respectively, while the minimum $\%$ of agro-residues, softwood mechanical pulp, softwood chemical pulp and hardwood chemical pulp was present in coffee cup, paper plate, french fries box and paper bag respectively.

During 1998-2008, FBD outbreak survillenace system showed one out of ten FBD were caused due to B. cereus and $S$. aureus. Thus, the presence of these 


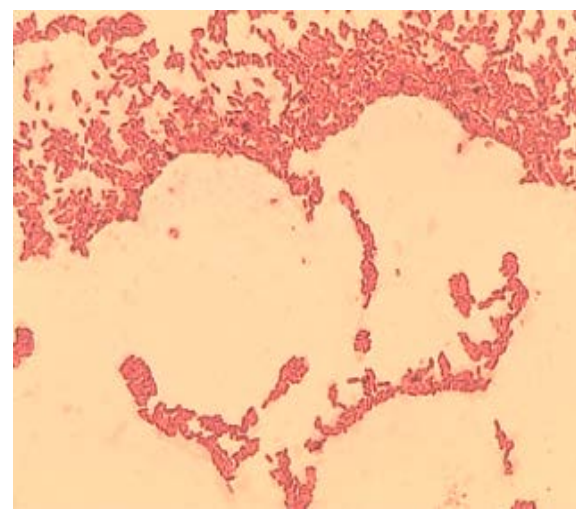

(a)

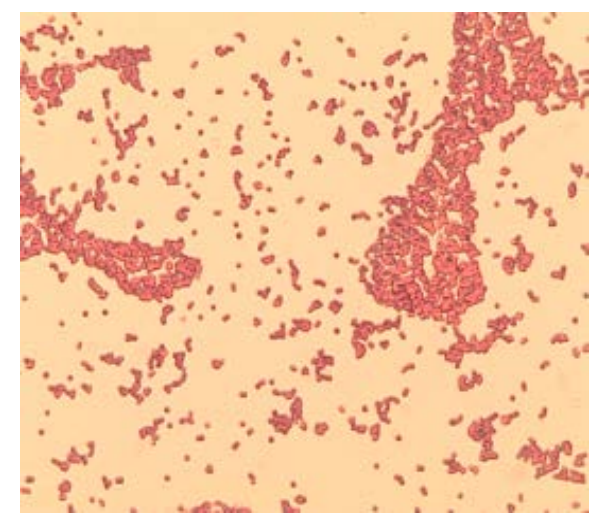

(c)

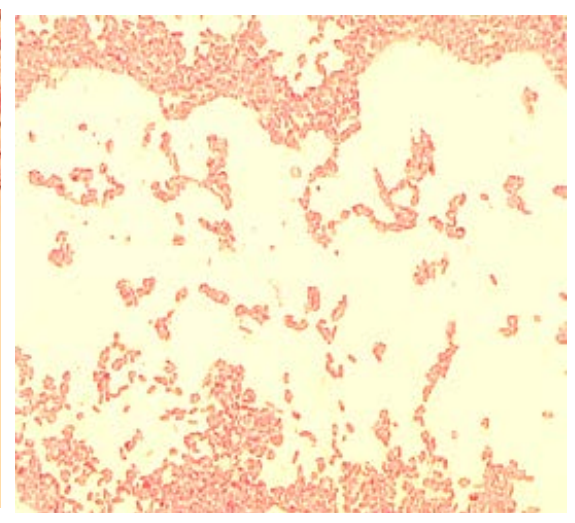

(b)

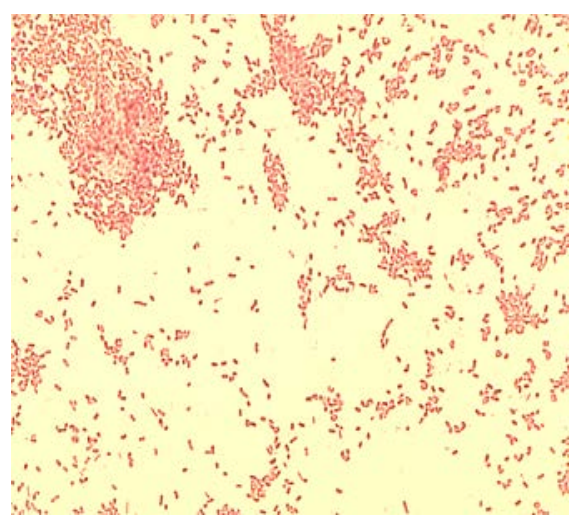

(d)

Figure 1. Microscopic images of identified bacteria (a) B. cereus, (b) B. subtilis, (c) S. aureus, (d) P. aeroginosa.

microbes in food packaging PPBs imposes potential hazard for consumers [20] [21]. In our study, B. cereus has been identified in cake box, pastry box, sweet box, and pizza box while, $S$. aureus has been identified in coffee cup and french fries box. The outcome of McCusky Gendron et al. showed that the samples they tested also contained microorganisms especially of Bacillus species [1]. It is believed that forming heat-resistant spores which describe its survival during the drying phase of paper board machine operation can be the main reason for finding Bacillus genera [22]. The aerobic bacteria genera mainly found in the paper industry include Baciilus and Pseudomonas [23]. P. aeroginosa was found in fruit tray samples while $B$. subtilis was present in paper plate, tissue paper, and paper bag. This is in agreement with Ibrahim and Sobeih finding who evaluated the effect of packaging containers on the bacteriological profile of cheese, the bacterial isolates in their study also included B. subtilis [24]. B. subtilis is a good source for the production of peroxidase enzyme [7] and a novel and thermostable lipoxygenase enzyme has been identified and characterized in $P$. aerogiosa [8], these enzymes act as catalysts to insert oxygen into fatty acid with methylene interrupted dienes contributing to oxidation of fatty acids by enzymes and hence odor generation in food packaging PPBs. Similar to these enzymes, globin proteins (hemoglobin and myoglobin) release ferric ion at high 
Table 2. Biochemical tests.

\begin{tabular}{|c|c|c|c|c|c|c|c|c|c|c|c|c|c|c|c|}
\hline Sample & 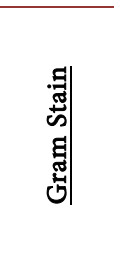 & 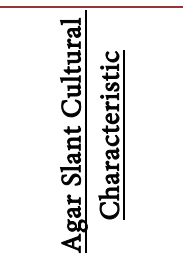 & 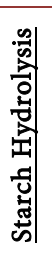 & 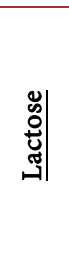 & 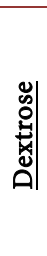 & 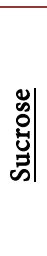 & 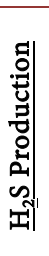 & 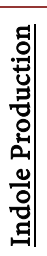 & 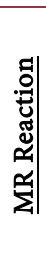 & 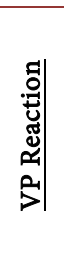 & 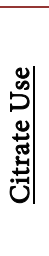 & 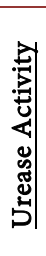 & 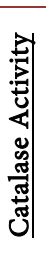 & 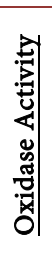 & 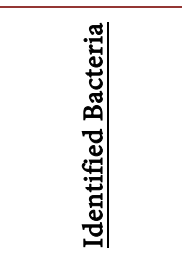 \\
\hline $\begin{array}{l}\text { Cake box, Pastry } \\
\text { box, Sweet box, } \\
\text { Pizza box }\end{array}$ & Rod+ & $\begin{array}{l}\text { Abundant, } \\
\text { opaque, white } \\
\text { waxy growth }\end{array}$ & + & - & $\mathrm{a}$ & a & - & - & - &,+- & - & - & - & + & Bacillus cereus \\
\hline $\begin{array}{l}\text { Paper plate, } \\
\text { Tissue paper, } \\
\text { Paper bag }\end{array}$ & Rod+ & $\begin{array}{l}\text { Abundant, } \\
\text { Dry, Flat, } \\
\text { Irregular }\end{array}$ & + &,+- & + & + & + & - & - & + & + & - & + &,+- & Bacillus subtilis \\
\hline $\begin{array}{c}\text { Coffee cup, } \\
\text { French fries box }\end{array}$ & Coccus+ & $\begin{array}{l}\text { Abundant, } \\
\text { opaque, } \\
\text { golden } \\
\text { growth }\end{array}$ & - & $a$ & $\mathrm{a}$ & $\mathrm{a}$ & - & - & + &,+- & - & - & + & - & $\begin{array}{c}\text { Staphylococcus } \\
\text { aureus }\end{array}$ \\
\hline Fruit tray & Rod- & $\begin{array}{l}\text { Abundant, } \\
\text { thin, white } \\
\text { medium } \\
\text { turns green }\end{array}$ & - & - & - & - & - & - & - & - & + & - & + & + & $\begin{array}{c}\text { Pseudomonas } \\
\text { aeruginosa }\end{array}$ \\
\hline
\end{tabular}

$+=$ positive, $-=$ negative,,$+-=$ variable reaction, $a=$ acid.

temperatures, and catalyze the production of odorous volatile oxidation products of fatty acids [9].

The Association of Food and Drug Officials (AFDO), states that if the simple process of packaging or repackaging operations does not occur under strict aseptic conditions and environment then it can result in contamination with pathogens. Testing for these organisms at particular control points prepares the best means of quality control. Contamination can be prevented by following the best techniques of continuous surveillance and good manufacturing practices [25].

\section{Conclusion}

It is essential to monitor the level of bacterial exposure to consumers through food PPBs, especially when the food comes in contact with the packages. The results inferred by the present study give an idea about the number and type of bacteria present in the Indian food PPBs that may cause health hazards, generate odors, etc. The source of bacteria Bacillus and Pseudomonas has been identified in agro-residues present in the raw material. The percentage of other pulp fibers like softwood mechanical pulp, softwood chemical pulp, and hardwood chemical pulp in the samples has also been determined. In summary, this is a comprehensive research on the occurrence of bacteria in various samples of Indian food packaging PPBs. The findings of this study will aid in understanding 


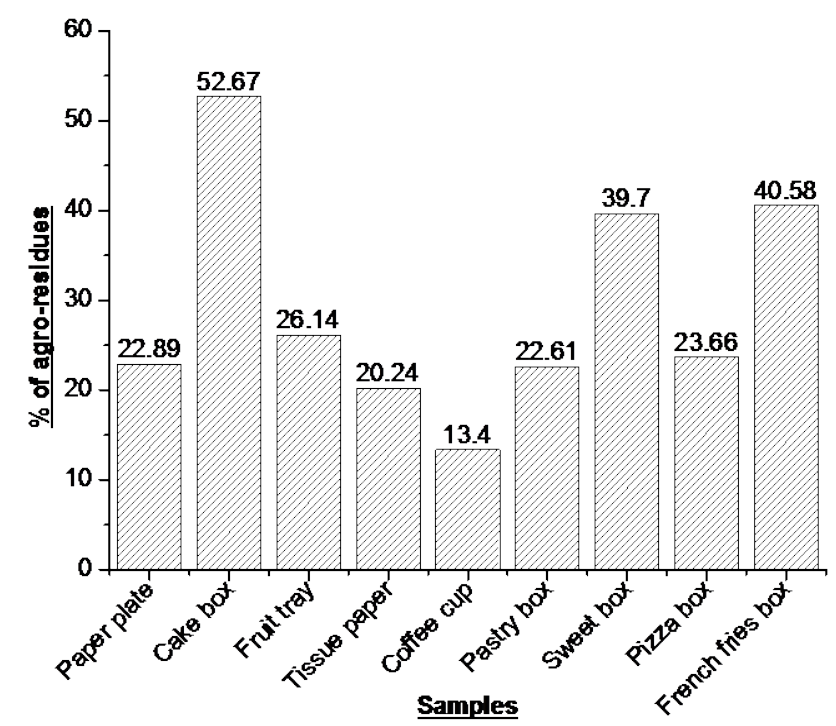

(a)

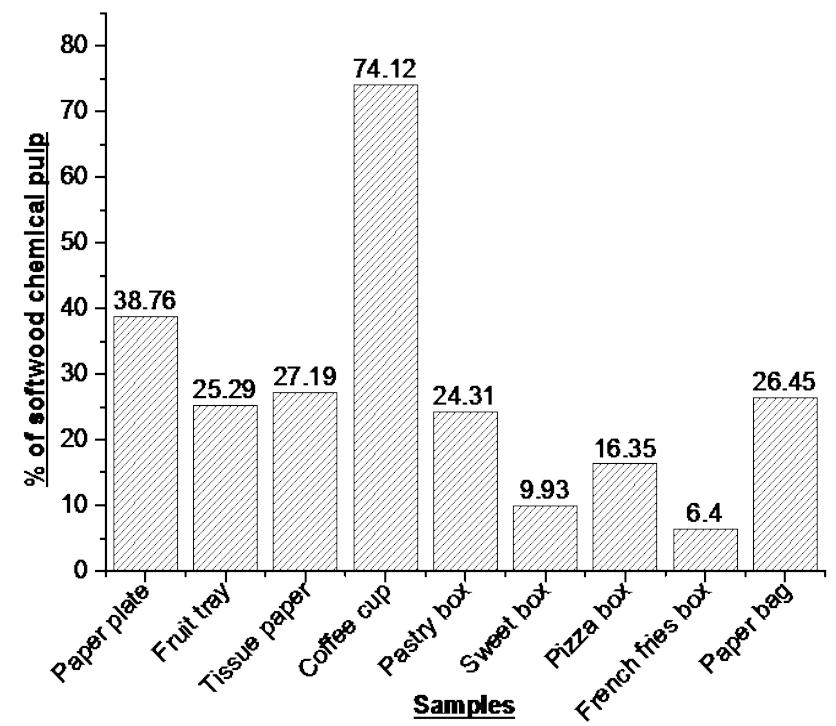

(c)

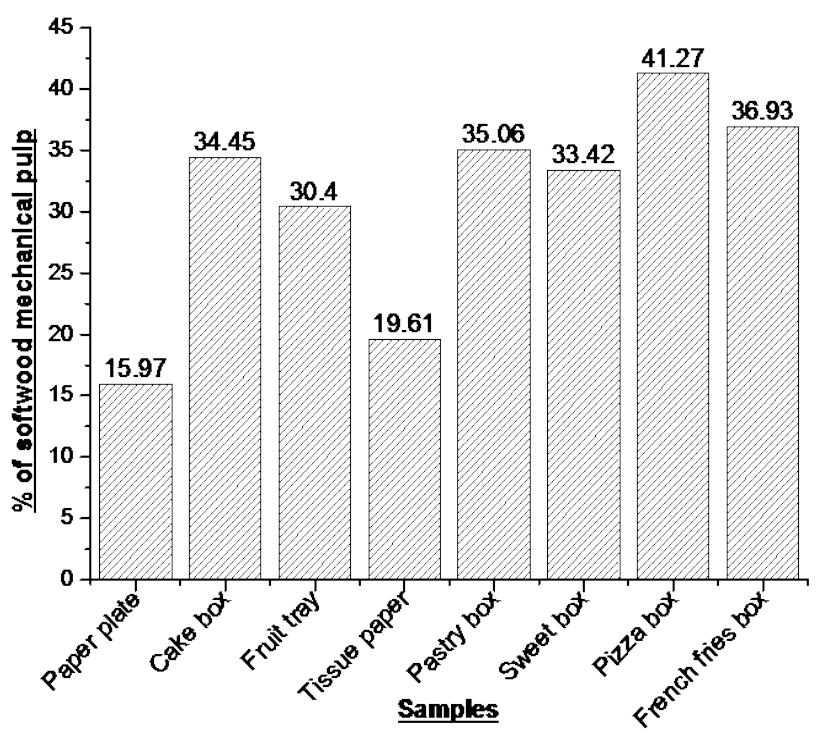

(b)

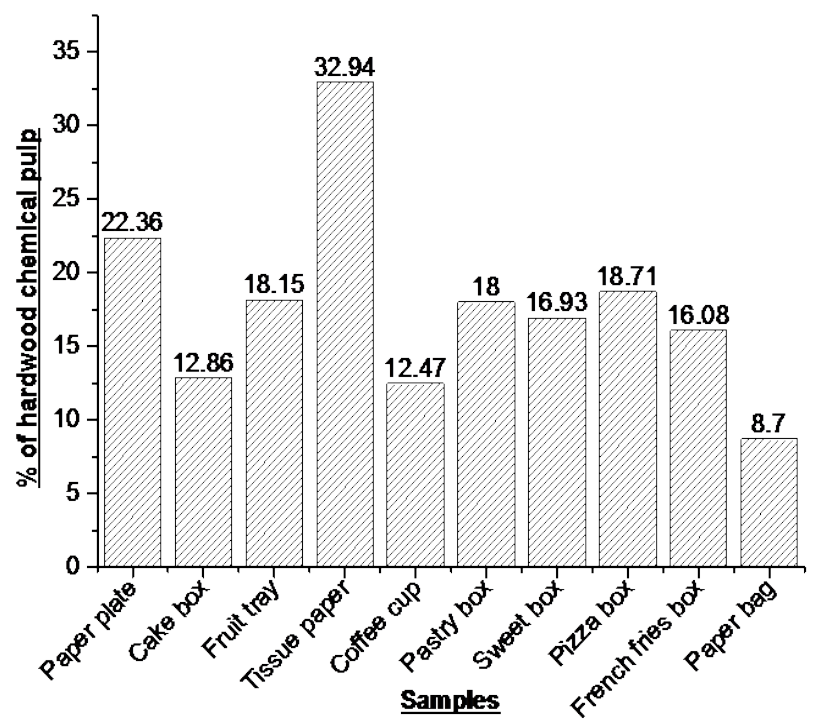

(d)

Figure 2. \% of pulp fiber in food PPB samples.

of the potential risk of rejection of food packages due to odorous compounds generation, which are catalyzed by enzymes produced by bacteria.

\section{Acknowledgements}

The authors are grateful to Central Instrumentation Facility, IIT Roorkee (SRE Campus) and Ministry of Human Resource Development (MHRD), India; fellowship contingency for carrying out this work.

\section{Conflicts of Interest}

The authors declare no conflicts of interest regarding the publication of this paper. 


\section{References}

[1] Hladikova, Z., Kejlova, K., Sosnovcova, J., Jirova, D., Vavrouš, A., Janoušek, A., Špelina, V., et al. (2015) Microbial Contamination of Paper-Based Food Contact Materials with Different Contents of Recycled Fiber. Czech Journal of Food Sciences, 33, 308-312. https://doi.org/10.17221/645/2014-CJFS

[2] Suihko, M.L., Sinkko, H., Partanen, L., Mattila-Sandholm, T., Salkinoja-Salonen, M. and Raaska, L. (2004) Description of Heterotrophic Bacteria Occurring in Paper Mills and Paper Products. Journal of Applied Microbiology, 97, 1228-1235. https://doi.org/10.1111/j.1365-2672.2004.02416.x

[3] Blanco, M.A., Negro, C., Gaspar, I. and Tijero, J. (1996) Slime Problems in the Paper and Board Industry. Applied Microbiology and Biotechnology, 46, 203-208. https://doi.org/10.1007/s002530050806

[4] Suihko, M.L. and Stackebrandt, E. (2003) Identification of Aerobic Mesophilic Bacilli Isolated from Board and Paper Products Containing Recycled Fibres. Journal of Applied Microbiology, 94, 25-34. https://doi.org/10.1046/j.1365-2672.2003.01803.x

[5] Cheng, J.H. (2016) Lipid Oxidation in Meat. Journal of Nutrition and Food Sciences, 6, 494.

[6] Jung, H. and Kappen, J. (2017) Odor Control in Papermaking. Paper Age, 7-8.

[7] Rao, P.R. and Kavya, P. (2014) Production, Isolation and Purification of Peroxidase Using Bacillus Subtilis.

[8] Bae, J.H., Hou, C.T. and Kim, H.R. (2010) Thermostable Lipoxygenase Is a Key Enzyme in the Conversion of Linoleic Acid to Trihydroxy-Octadecenoic Acid by Pseudomonas aeruginosa PR3. Biotechnology and Bioprocess Engineering, 15, 1022-1030. https://doi.org/10.1007/s12257-010-0273-y

[9] Devine, C. and Dikeman, M. (2014) Encyclopedia of Meat Sciences. Elsevier, Amsterdam.

[10] Väisänen, O., Elo, S., Marmo, S. and Salkinoja-Salonen, M. (1989) Enzymatic Characterization of Bacilli from Food Packaging Paper and Board Machines. Journal of Industrial Microbiology, 4, 419-428. https://doi.org/10.1007/BF01569637

[11] Rao, M.R.K., Sivagnanam, S.K. and Syed, F.B. (2016) Isolation, Characterization and Identification of Predominant Microorganisms from Agro-Waste.

[12] Pirttijärvi, T.S.M., Graeffe, T.H. and Salkinoja-Salonen, M.S. (1996) Bacterial Contaminants in Liquid Packaging Boards: Assessment of Potential for Food Spoilage. Journal of Applied Bacteriology, 81, 445-458. https://doi.org/10.1111/j.1365-2672.1996.tb03532.x

[13] Aneja, K.R. (2007) Experiments in Microbiology, Plant Pathology and Biotechnology. New Age International.

[14] Mohammadzadeh-Vazifeh, M.M., Hosseini, S.M., Khajeh-Nasiri, S., Hashemi, S. and Fakhari, J. (2015) Isolation and Identification of Bacteria from Paperboard Food Packaging. Iranian Journal of Microbiology, 7, 287.

[15] Pirttijärvi, T. (2000) Contaminant Aerobic Sporeforming Bacteria in the Manufacturing Processes of Food Packaging Board and Food.

[16] Suihko, M.L. and Skyttä, E. (1997) A Study of the Microflora of Some Recycled Fibre Pulps, Boards and Kitchen Rolls. Journal of Applied Microbiology, 83, 199-207. https://doi.org/10.1046/j.1365-2672.1997.00219.x

[17] Guzińska, K., Owczarek, M. and Dymel, M. (2012) Investigation in the Microbiological Purity of Paper and Board Packaging Intended for Contact with Food. Fibres 
\& Textiles in Eastern Europe.

[18] Fleiter, T., Fehrenbach, D., Worrell, E. and Eichhammer, W. (2012) Energy Efficiency in the German Pulp and Paper Industry-A Model-Based Assessment of Saving potentials. Energy, 40, 84-99. https://doi.org/10.1016/j.energy.2012.02.025

[19] Gellerstedt, G. (2009) Chemistry of Chemical Pulping. Pulping Chemistry and Technology, 2, 91-120.

[20] Bennett, S.D., Walsh, K.A. and Gould, L.H. (2013) Foodborne Disease Outbreaks Caused by Bacillus cereus, Clostridium perfringens, and Staphylococcus aureus-United States, 1998-2008. Clinical Infectious Diseases, 57, 425-433. https://doi.org/10.1093/cid/cit244

[21] Kadariya, J., Smith, T.C. and Thapaliya, D. (2014) Staphylococcus aureus and Staphylococcal Food-Borne Disease: An Ongoing Challenge in Public Health. BioMed Research International, 2014, Article ID: 827965.

[22] Kemppainen, H. (2013) Mapping of Causations for Edospore Formation and Process Optimization at Pulp- and Paper Mill.

[23] Bajpai, P. (2015) Pulp and Paper Industry: Microbiological Issues in Papermaking. Elsevier, Amsterdam.

[24] Ibrahim, E. and Sobeih, A. (2010) Effect of Packaging Containers on the Bacteriological Profile of Soft Cheese. Global Veterinaria, 4, 349-356.

[25] Nma, N.O. and Ola, A. (2013) Microbiological Analysis of Some Packaged Fruit Juices Sold in Port Harcourt Metropolis, Nigeria. Nature and Science, 11, 30-40. 